\title{
Organoleptic and Microbial Quality of Ice Cream Sold at Retail Stores in Mymensingh, Bangladesh
}

\author{
K. M. Mahmud Hossain, S. M. Lutful Kabir*, M. Mufizur Rahman, M. Bahanur Rahman, \\ Khair Ahmed Choudhury
}

Department of Microbiology and Hygiene, Faculty of Veterinary Science, Bangladesh Agricultural University, Mymensingh-2202, Bangladesh

\begin{abstract}
A study was conducted to assess the sanitary quality of ice cream manufactured by five different plants namely Milk vita, Igloo, Polar, Savoy and Kwality sold in retail stores in Mymensingh Town, Bangladesh. The result revealed the average total viable counts which were $3267 \mathrm{CFU} / \mathrm{ml}(\log 3.5)$ in Milk vita, $3500 \mathrm{CFU} / \mathrm{ml}(\log 3.5)$ in Igloo, $13833 \mathrm{CFU} / \mathrm{ml}$ ( $\log 4.1)$ in Polar, $16500 \mathrm{CFU} / \mathrm{ml}(\log 4.2)$ in Savoy and 20916 CFU/ml (log 4.3) in Kwality ice cream samples. It was found that the highest extent of microbial contamination and proliferation of viable bacteria occurred in Kwality ice cream. The average coliform counts obtained from the study was in milk vita $0.33 \mathrm{CFU} / \mathrm{ml}(\log -0.5)$ and igloo $0.0 \mathrm{CFU} / \mathrm{ml}(\log 0.0)$, Polar16500 CFU/ml (log 4.2), Savoy 16500 CFU/ml (log 4.2), Kwality 20916 CFU/ml (log 4.3) and the presence of numbers of coliforms in Polar, Savoy and Kwality ice creams samples were fairly high $(10 / \mathrm{ml})$ indicated the poor hygienic practices during manufacture, post process contamination and unsatisfactory transportation. Statistically the coliforms were found more closely related to total viable counts than the staphylococcal counts. The average staphylococcal counts as revealed in the samples of Milk vita, Igloo, Polar, Savoy and Kwality were $0.5 \mathrm{CFU} / \mathrm{ml}(\log -0.3), 0.0 \mathrm{CFU} / \mathrm{ml}(\log 0.0), 4.33 \mathrm{CFU} / \mathrm{ml}$ $(\log 0.6), 8.8 \mathrm{CFU} / \mathrm{ml}(\log 0.9)$ and $4.4 \mathrm{CFU} / \mathrm{ml}(\log 0.6)$ respectively may present cause for alarm which could be associated with potential food poisoning hazards. The results demonstrated that Igloo and Milk vita ice creams are of the superior quality product in respect of sanitary condition.
\end{abstract}

Keywords Ice Cream, Organoleptic Quality, Microbial Quality

\section{Introduction}

Ice cream is a delicious, wholesome, nutritious frozen dairy food. It is made of milk, sweet cream, skim milk, condensed milk or other concentrated dairy products or a combination of these with added sugar, flavoring and stabilizer with or without color and with incorporation of air during the freezing process[1]. Ice cream is undoubtedly one of most popular and favorite food product in Bangladesh among children and adults especially during summer season. Several brands of ice cream in variety of flavors have been marketed here.

Quality of ice cream depends on both extrinsic factors that include manufacture procedure, and intrinsic factors that include proportion of ingredients used[2]. Ice cream, a milk based product is good media for microbial growth due to high nutrient value, almost neutral $\mathrm{pH}$ value and long storage duration. Primary sources of microbial contamination to ice cream include water and raw milk whereas secondary sources include flavoring agents, utensils and handling.

* Corresponding author:

1kabir79@gmail.com (S. M. Lutful Kabir)

Published online at http://journal.sapub.org/microbiology

Copyright (C) 2012 Scientific \& Academic Publishing. All Rights Reserved
Although pasteurization, freezing and hardening steps in production can estimate most of the microbial hazards, but still numerous health hazards are persistent due to various conditions[3]. Many psychrophiles and psychrotolerant microorganisms like Listeria monocytogens, Staphylococcus aureus, Bacillus, Salmonella, Shigella, Streptococus, Pseudomonas, Campylobacter, Brucella and other bacteria are generally present in ice cream[4].

In all developed countries the establishment of ice cream industry has promoted to build up improvement in health and economic well being of the nation. Unfortunately in Bangladesh keeping in view the coherent consumer's protection policies, there has been made very limited development of ice cream industries like savoy, polar, kwality, igloo, milk vita etc. Since Bangladesh does not have any organized food control service to ensure safety of food supplies, it is very difficult to ascertain whether the ice cream produced and distributed in our country is hygienically safe and without any public health hazard. Therefore, the present study was designed to determine the organoleptic and microbial quality of ice cream sold at retail stores in Mymensingh, Bangladesh. 


\subsection{Sources, Collection and Transportation of Samples}

This experiment was carried out in the Microbiology Laboratory of Bangladesh Agricultural University, Mymensingh from 1 January to 1 April, 2005. Ice creams prepared by five manufactures (Savoy, Polar, Kwality, Igloo, Milk Vita) were collected for this study. A total of six ice cream samples of each brand was obtained from the retail stores to determine organelles properties and microbiological qualities. Prior to sale the shopkeepers of the retail stores kept ice cream packages or cups in a deep freeze cabinet. Aseptic measure was taken during the collection of ice cream samples. The samples constitute unopened packages or tubes which were delivered intact to the laboratory. All samples were transported in an insulated container packed in ice and brought to the laboratory within half an hours for sampling and subsequent studies.

\subsection{Preparation of Samples}

Prior to taking samples, the ice cream was kept in water bath at $45^{\circ} \mathrm{C}$ as per recommendation of Harrigan and McCance[5]; Rahman[6]. After thawing \& when complete liquefaction from the top is so opened that the sterile piptte could be introduced for collection of samples. A quantity of about $10 \mathrm{ml}$ of liquid ice cream was pipetted out from different depths and transferred into a sterile glass bottle fitted with a screw capped stopper. Six cups of ice cream of each brand were handled as above and the samples were taken in the lebelled bottles. In this way a total quantity of $60 \mathrm{ml}$ of the ice cream sample was collected from each brand. The collected ice cream was considered as a single representative sample. From this thoroughly mixed sample, an exact quantity of $1 \mathrm{ml}$ of ice cream was pipetted out aseptically and transferred into a sterile empty test tube and plugged with cotton. To this ice cream $9 \mathrm{ml}$ of diluent was added to give a 1:10 dilution $\mathrm{v} / \mathrm{v}$. The choice of dilution for the preparation of samples was sterile $0.1 \%$ peptone water at $\mathrm{pH}$ 6.8-7.0. Further decimal dilutions as required were prepared according to standard method given by APHA[7-9].

\subsection{Judging of Samples}

The samples were judged separately by a panel expert of judges to evaluate appearance, color, odor, and overall characteristics, using a standard score card for judging ice cream. For scoring sensory characteristics hedonic scales were used in which scores 19-20 = Excellent; 16-18 = Good; 12-15 = Fair, 9-11 = Marginal acceptable; 7-8 = Unacceptable; $0-6=$ Bad. For each of the characteristic, the maximum score given was 20 points. The total scores marked thus for the five characteristic parameter was 100 points.

\subsection{Enumeration of Total Viable Count (TVC)}

For the determination of total bacterial count, $0.1 \mathrm{ml}$ of each ten-fold dilution was transferred and spread on duplicate nutrient agar using a fresh pipette for each dilution. The diluted samples were spread as quickly as possible on the surface of the plate with a sterile glass spreader. One sterile spreader was used for each plate. The plates were then kept in an incubator at $30^{\circ} \mathrm{C}$ for $24-48$ hours. Following incubation, plates exhibiting 30-300 colonies were counted. The average number of colonies in a particular dilution was multiplied by the dilution factor to obtain the total viable count. The total viable count was calculated according to ISO[10]. The results of the total bacterial count were expressed as the number of organism or colony forming units per gram $(\mathrm{CFU} / \mathrm{gm})$ of ice cream sample.

\subsection{Enumeration of Total Coliform Count (TCC)}

For the determination of total coliform count $1 \mathrm{ml}$ of each tenfold dilution was transferred to MacConkey agar. For each dilution five test plates containing MacConkey agar were used. All the agar plates were incubated at $30^{\circ} \mathrm{C}$ temperature for 48 hours. The total coliform count was calculated according to ISO[10]. The results of the total coliform count were expressed as the number of organism or colony forming units per gram (CFU/gm) of ice cream sample.

\subsection{Enumeration of Total Staphylococcal Count (TSC)}

For the determination of total staphylococcal count $1 \mathrm{ml}$ of each tenfold dilution was transferred to mannitol salt agar. For each dilution five test plate containing Mannitol salt agar were used. All the agar plates were incubated at $37^{\circ} \mathrm{C}$ temperature for 48 hours. The total staphylococcal count was calculated according to ISO[10]. The results of the total staphylococcal count were expressed as the number of organism or colony forming units per gram $(\mathrm{CFU} / \mathrm{gm})$ of ice cream sample. A total of 6 samples of each brand was bacteriologically examined. The results were recorded and the organoleptic and microbiological quality was determined.

\subsection{Statistical Analysis}

The data obtained from examination of 5 brands of commercial ice cream samples were statistically analyzed. The means for all the samples were calculated and analysis of variances for different bacterial counts were performed by $F$ variance test. The differences between means were evaluated by Duncun's New Multiple Range Test (DMRT) ac cording to Gomez and Gomez[11].

\section{Results and Discussion}

A number of thirty commercially produced ice cream samples belonging to five different brands were collected from different retail stores located at Mymensingh town. All the samples were transported in an ice box and kept in the deep freezer of the laboratory until use. Thereafter, the sensory and microbiological attribute were analyzed and studied comparatively. Sensory characteristics were judged by a panel of experts and judgement for consumer's acceptance are scored. A presentation of the data showing the scores of characteristics of different ice cream samples are shown in Table 1. Sensory characteristics of hedonic scales obtaining scores 19-20 indicate excellent quality and 16-18 indicate 
good quality, 12-15 means fair; 9-11 scores recommend marginal acceptable; 7-8 considered unacceptable; 0-6 stands for bad. Five organoleptic quality characteristics were taken for the panel score and judgement for consumer's acceptance. For each of the characteristic, the maximum score given was 20 points. The grand total scores for the five characteristic parameters together become 100 points. Out of total score points 100 , five different brand of ice cream samples were found to have obtained for Igloo $90(90 \%)$ followed by Milk vita $82(82 \%)$, Savoy 76 (76\%), Polar 68 $(68 \%)$ and Kwality 57 (57\%) scores. The highest score of 90 was obtained by Igloo and the low score of 57 stands for Kwality ice cream. According to total score of sensory characteristics, it can be said that qualitatively Milk vita is very much near to the Igloo ice cream. It is evident from the overall organoleptic quality result that ice cream samples of Igloo possessed the most superior quality, and has been liked by most of the taste panel exports. Ice cream samples were examined bacteriologically to investigate the presence of total viable microorganisms and thereby assess the sanitary quality.

The result presented in Table 2 showed the total viable bacterial load of 30 different ice cream samples of six different brands. The bacterial loads found were not uniform and varied quite considerably. The average counts $/ \mathrm{ml}$ of Milk vita, Igloo, Polar, Savoy and Kwality were 3,267 $\mathrm{CFU} / \mathrm{ml}(\log 3.5), 3,500 \mathrm{CFU} / \mathrm{ml}(\log 3.5), 13,833 \mathrm{CFU} / \mathrm{ml}$ ( $\log 4.1), 16,500 \mathrm{CFU} / \mathrm{ml}(\log 4.2)$, and 20,916 CFU/ml (log 4.3). The maximum and minimum range of total bacterial load per $\mathrm{ml}$ of ice cream samples belonging to Milk vita, Igloo, Polar, Savoy and Kwality varied from $\log 3.6$ to $\log$ 3.5, $\log 3.7$ to $\log 3.4, \log 4.3$ to $\log 4.0, \log 4.3$ to $\log 4.0$ and $\log 4.4$ to $\log 4.2$ respectively (Tables 3 ). The average total viable counts of all the five brands of ice cream was 11603.2 $\mathrm{CFU} / \mathrm{ml}(\log 4.1)$ (Table 2). The assessment of total viable count as revealed in Table 2 has clearly provided information that the ice cream samples of Milk vita and Igloo were of the superior quality, because the counts were less than the recommended microbiological standard of Food and Drug administration and USPHS[12]. All brands of ice cream samples were within acceptable limit of public health safety because the samples did not exceed the total viable count $(1$, $00,000 \mathrm{CFU} / \mathrm{ml}$ ) permitted under regulation[2,13].

Table 1. Sensory characteristics of commercially produced ice cream and taste panel scores expressed in hedonic scales

\begin{tabular}{|c|c|c|c|c|c|c|}
\hline \multirow{2}{*}{ Parameters (Sensory Characteristic) } & \multicolumn{5}{|c|}{ Sources of Ice Cream Samples } \\
\cline { 3 - 7 } & 20 Marks & Milk Vita & Igloo & Polar & Savoy & Kwality \\
\hline Appearance & 18 & 19 & 13 & 16 & 14 \\
\hline Color & 20 Marks & 17 & 18 & 17 & 15 & 12 \\
\hline Odor & 20 Marks & 16 & 17 & 11 & 16 & 11 \\
\hline Texture & 20 Marks & 18 & 18 & 15 & 14 & 10 \\
\hline Overall Characteristics & 20 Marks & 17 & 18 & 12 & 15 & 11 \\
\hline \multicolumn{2}{|l}{ Grand Total Score (100 Marks) } & 86 & 90 & 68 & 76 & 57 \\
\hline
\end{tabular}

Table 2. Density of average total viable bacteria and other selected microbial groups in per gram of ice cream samples of different brands

\begin{tabular}{|c|c|c|c|c|c|c|c|}
\hline \multirow{2}{*}{$\begin{array}{c}\text { Sources of ice } \\
\text { cream samples }\end{array}$} & No. of samples & \multicolumn{2}{|c|}{ Total viable count/ml } & \multicolumn{2}{c|}{ Coliform count/ml } & \multicolumn{2}{c|}{ Staphylococcal count/ml } \\
\cline { 3 - 8 } & analyzed & CFU & Log & CFU & Log & CFU & Log \\
\hline Milk vita & 06 & 3267 & 3.5 & 0.3 & -0.5 & 0.5 & -0.3 \\
\hline Igloo & 06 & 3500 & 3.5 & 0.0 & 0.0 & 0.0 & 0.0 \\
\hline Polar & 06 & 13833 & 4.1 & 12.5 & 1.1 & 4.3 & 0.6 \\
\hline Savoy & 06 & 16500 & 4.2 & 19.16 & 1.3 & 8.8 & 0.9 \\
\hline Kwality & 06 & 20916 & 4.3 & 22 & 1.3 & 8.2 & 0.9 \\
\hline Average & - & 11603.2 & 4.1 & 10.7 & 1.0 & 4.4 & 0.6 \\
\hline
\end{tabular}

Table 3. Range of total viable bacterial concentration in commercial ice cream samples

\begin{tabular}{|c|c|c|c|c|c|}
\hline \multirow{2}{*}{ Brand specification } & \multirow{2}{*}{$\begin{array}{c}\text { No. of samples } \\
\text { analyzed }\end{array}$} & \multicolumn{2}{|c|}{ Range of TVC/ml } & \multirow{2}{*}{$\begin{array}{c}\text { Average TVC/ml } \\
\text { (mean value) }\end{array}$} & $\begin{array}{c}\text { Standard devia- } \\
\text { tion }\end{array}$ \\
\cline { 3 - 4 } & 06 & Maximum & Minimum & 3.5 & 280.5 \\
\hline Milk vita & 06 & 3.6 & 3.5 & 3.5 & 723.9 \\
\hline Igloo & 06 & 4.3 & 4.0 & 4.1 & 4355.1 \\
\hline Polar & 06 & 4.3 & 4.0 & 4.2 & 3391.2 \\
\hline Savoy & 06 & 4.4 & 4.2 & 4.3 & 1249.7 \\
\hline Kwality & 06 &
\end{tabular}

All counts are expressed in logarithms

Table 4. Range of Coliform counts in commercial ice cream samples

\begin{tabular}{|c|c|c|c|c|c|}
\hline \multirow{2}{*}{$\begin{array}{c}\text { Brand } \\
\text { specification }\end{array}$} & \multirow{2}{*}{$\begin{array}{c}\text { No. of samples } \\
\text { analyzed }\end{array}$} & \multicolumn{2}{|c|}{ Range of coliform count/ml } & \multirow{2}{*}{$\begin{array}{c}\text { Average coliform } \\
\text { count } / \mathrm{ml} \text { (mean value) }\end{array}$} & \multirow{2}{*}{ Standard deviation } \\
\hline & & Maximum & Minimum & & \\
\hline Milk vita & 06 & 0.0 & 0.0 & -0.5 & 0.5 \\
\hline Igloo & 06 & 0.0 & 0.0 & 0.0 & 0.0 \\
\hline Polar & 06 & 1.3 & 1.0 & 1.1 & 4.3 \\
\hline Savoy & 06 & 1.4 & 1.0 & 1.3 & 6.0 \\
\hline Kwality & 06 & 1.6 & 1.2 & 1.3 & 7.3 \\
\hline
\end{tabular}

All counts are expressed are logarithms 
Table 5. Range of Staphylococcal counts in commercial ice cream samples

\begin{tabular}{|c|c|c|c|c|c|}
\hline \multirow{2}{*}{$\begin{array}{c}\text { Brand speci- } \\
\text { fication }\end{array}$} & $\begin{array}{c}\text { No. of samples } \\
\text { analyzed }\end{array}$ & \multicolumn{2}{|c|}{ Range of Staphylococcal count/ml } & \multirow{2}{*}{$\begin{array}{c}\text { Average Staphylococcal } \\
\text { count/ml (mean value) }\end{array}$} & Standard deviation \\
\cline { 3 - 4 } & 06 & Maximum & Minimum & -0.3 & 0.6 \\
\hline Milk vita & 06 & 0.0 & 0.0 & 0.0 & 0.0 \\
\hline Igloo & 06 & 0.8 & 0.0 & 0.6 & 1.7 \\
\hline Polar & 06 & 1.1 & 0.3 & 0.9 & 2.6 \\
\hline Savoy & 06 & 1.1 & 0.6 & 0.9 & 3.4 \\
\hline Kwality & 06 & & & \\
\hline
\end{tabular}

All counts are expressed are logarithms.

Table 6. Statistical analysis of ice-cream brand samples in relation to Total viable, Coliform and Staphylococcal counts

\begin{tabular}{|c|c|c|c|}
\hline Types of ice cream & Total viable count & Coliform count & Staphylococcal count \\
\hline Milk vita & $3267 \mathrm{c}$ & $0.3 \mathrm{c}$ & $0.5 \mathrm{c}$ \\
\hline Igloo & $3500 \mathrm{c}$ & $0.0 \mathrm{c}$ & $0.0 \mathrm{c}$ \\
\hline Polar & $13833 \mathrm{~b}$ & $12.5 \mathrm{~b}$ & $4.3 \mathrm{~b}$ \\
\hline Savoy & $16500 \mathrm{~b}$ & $19.2 \mathrm{a}$ & $8.8 \mathrm{a}$ \\
\hline Kwality & $20917 \mathrm{a}$ & $22 \mathrm{a}$ & $8.2 \mathrm{a}$ \\
\hline CV $(\%)$ & 26.38 & 43.3 & 48.2 \\
\hline Sd & 3061.1 & 4.7 & 2.1 \\
\hline LSD at $1 \%$ level & 3640 & 5.6 & 2.5 \\
\hline
\end{tabular}

* a to c rank order (highest - lowest)

Table 7. Ratio relationship between Total viable bacterial count and Coliform density per/ml portion of ice cream samples of different brands

\begin{tabular}{|c|c|c|c|c|}
\hline Brand & No. of sample analyzed & Average total viable count/ml & Average coliform count/ml & Ratio coliform: TVC \\
\hline Milk vita & 06 & 3266.7 & 0.3 & $1: 9899$ \\
\hline Igloo & 06 & 3500 & 0.0 & $1: \alpha$ \\
\hline Polar & 06 & 13833.3 & 12.5 & $1: 1106.7$ \\
\hline Savoy & 06 & 16500 & 19.2 & $1: 860.7$ \\
\hline Kwality & 06 & 20916.7 & 22 & $1: 950.8$ \\
\hline
\end{tabular}

Coliform counts were found in highest density in Kwality and lowest in Igloo ice cream (Table 2). The average count $/ \mathrm{ml}$ was observed in samples belong to Kwality log 1.3 followed by Savoy $\log 1.3$, Polar $\log 1.1$, Milk vita $\log -0.5$ and Igloo log 0.0 respectively (Table 4). It is evident from the result that the average coliform count was $10.7 \mathrm{CFU} / \mathrm{ml}$ ( $\log 1.0)$ (Table 2). The coliform standards for ice cream should not be over $10 / \mathrm{ml}[14,15]$. The present investigation however showed significantly high coliform counts in samples belonging to Polar, Savoy and Kwality ice cream. However, this study demonstrated that the samples of Milk vita and Igloo met the recommended criteria of USPHS[12]. Hence, it could be taken into consideration as superior quality ice cream. It is known that coliforms play role in determining the hygienic quality index of food. In this study, coliform counts positively and significantly correlated with total viable count of different brands of commercial ice cream $\left(\mathrm{R}^{2}=0.842\right)$ as shown in Fig. 1. Siva et al.,[16] observed the similar evidence $\left(\mathrm{R}^{2}=0.843\right)$.

The average staphylococcal counts $/ \mathrm{ml}$ in different brand of ice cream samples were Milk vita $0.5 \mathrm{CFU} / \mathrm{ml}(\log 0.0)$, Igloo $0.0 \mathrm{CFU} / \mathrm{ml}(\log 0.0)$. Polar $4.3 \mathrm{CFU} / \mathrm{ml}(\log 0.6)$, Savoy $8.8 \mathrm{CFU} / \mathrm{ml}(\log 0.9)$ and Kwality $8.2(\log 0.9)$ (Table 2 ). The maximum and minimum ranges varied from $\log 0.0$ to $\log 0.0$ in Milk vita ice cream, $\log 0.8$ to $\log 0.3$ in Polar ice cream, $\log 1.1$ to $\log 0.7$ in Savoy ice cream and $\log 1.1$ to $\log 0.6$ in Kwality ice cream respectively (Table 5). The average staphylococcal counts of all five brands of ice cream was $4.4 \mathrm{CFU} / \mathrm{ml}(\log 0.6)$ (Table 2). However, the highest count was observed in Savoy ice cream sample and the lowest was obtained in Igloo ice cream sample. In certain situation staphylococci organisms particularly $S$. aureus may be a pathogen, a source of enterotoxin and indicator of unsanitary practice. In man, the main reservoir of $S$. aureus is the nasal cavity and skin. From these sources staphylococci find their way into air and dust, into clothings and in other place from which foods get contaminated. Since staphylococcal food poisoning is an intoxication and depends on the ability of food concerned to support the growth of the staphylococci which produce the toxin. It is therefore important to consider that the processing and handling of the food products should be so designed to minimize contamination and to make unfavourable medium for the growth of these organisms. When susceptible foods are produced with low numbers of staphylococci, they will remain free of enterotoxin if kept either below $4^{\circ} \mathrm{C}$ until consumed. The factors that contribute mostly to staphylococcal food-borne outbreaks may be due to inadequate refrigeration, preparing food far in advance of planned service, infected persons practicing poor personal hygiene, inadequate heat processing and holding food in warming devices at bacterial growth temperature. Pelezar et al.,[17] stated that staphylococci may come into milk and milk product from food handlers who may have acute infections or from healthy carriers who harbor the organisms in their nose or throats and also it is due to improperly stored and refrigerated milk and milk product that make excellent culture media for growth of these organisms. 


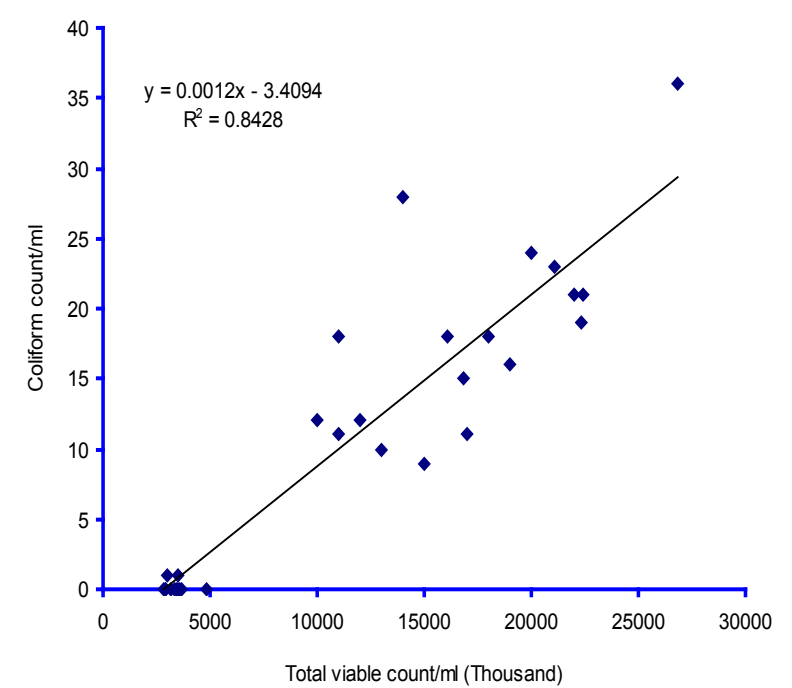

Figure 1. Relationship between coliform count and total viable count of different ice cream samples

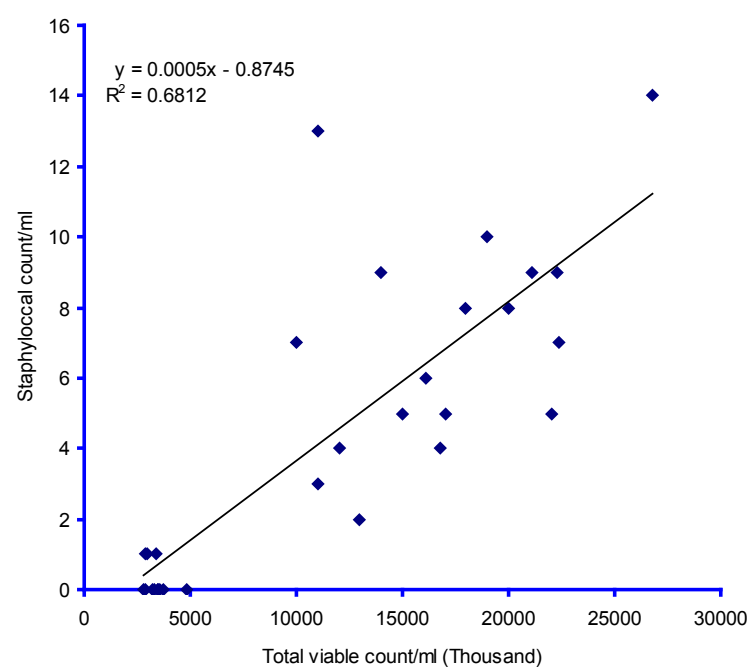

Figure 2. Relationship between staphylococcal count and total viable count of different ice cream samples

From Table 6 considering the total viable count and coliform count the ice cream samples of Milk vita and Igloo ranked order into 'c', Polar 'b', Savoy and Kwality sample ' $a$ '. This ranked order was arranged numerically. In case of total viable count of five brands of commercial ice cream samples, coefficient of variation (cv) was $26.38 \%$ and $\mathrm{Sd}$ was 3061.08 and for coliform count cv was $43.34 \%$ and $\mathrm{Sd}$ was 4.68 (Table 6). The analysis demonstrated that from the bacteriological context the lower count of bacteria in any food product signified comparatively better quality product, of course it should have to meet with international standard. In this respect ice cream sample of Milk vita and Igloo were the best criterion quality product and also it fulfilled the gradation 'c'. Savoy and Kwality samples were of poor quality and graded into 'a' categories. In case of staphylococcal count, Milk vita and Igloo samples ranked order into 'c' Polar samples 'b', Savoy and Kwality samples ' $a$ '. It is also numerically arranged and in this context Milk vita and Polar samples were of the best quality product. For Staphy- lococcal count of these five brands of commercial ice cream $\mathrm{cv}$ was $4.8 \%$ and $\mathrm{Sd}$ was 2.1 (Table 6). The results demonstrated that Igloo ice cream is the best quality product in respect of bacteriological context as well as hygienic point of view.

In this study, a ratio relationship obtained between Total viable count and Coliform count of five brands of ice cream separately. These were in case of Milk vita 1: 9899, Igloo, 1: $\alpha$, Polar, 1: 1106.7; Savoy, 1: 860.7 and Kwality 1: 950.8 (Table 7). From this result, a conclusion could be drawn that higher density of total viable count always contained less number of Coliforms, since coliform is the index of sanitary quality, the ice cream samples of Igloo were best and also Milk vita have been found to possess the property of hygienically produced ice cream.

In this study, Staphylococcal counts were positively and significantly correlated with total viable count in different brands of commercial ice cream. The regression equation and correlation value were $\mathrm{y}=0.0005 \mathrm{x}-0.8745$, and $\mathrm{R}^{2}=$ 0.6812 respectively (Fig. 2). Coliform counts were also correlated with total viable count in different brands of commercial ice cream $\left(\mathrm{y}=0.0012 \mathrm{x}-3.4094, \mathrm{R}^{2}=0.8428\right.$ (Fig. 1).

Microbial quality of ice cream examined in Nepal by Joshi et al.,[3], in Hongkong by Food and Environmental Hygiene Department[18], in Phillipines by Orallo et al.,[19] and in India by Bhusan Reddy et al.,[20] also reported the more or less comparable results.

\section{Conclusions}

From the present results, it was concluded that Igloo and Milk vita ice cream are of the superior quality product in respect of sanitary condition in Bangladesh. However, much attention is still needed to apply aspects of microbiological quality control for attaining desired safety margins and giving assurance that the ice cream product received by the consumer will be pure, healthful and of the quality claimed. To do so useful and effective sound legislation must have to be enacted and enforced, the chief aim of which is to ensure that the production, handling, processing, distribution and storage of ice cream could be maintained under strict hygienic control to protect consumers against health hazard and under quality standards.

\section{ACKNOWLEDGEMENTS}

The authors thank Dr. Hemanta Koley, Division of Bacteriology, National Institute of Cholera and Enteric Diseases, Kolkata, India for critically reading the manuscript.

\section{Conflict of Interest}

None to declare. 


\section{REFERENCES}

[1] Arbucle, W. S., and Frandsen, J. H. M. S., 1966, Study on ice cream and related products. $3^{\text {rd }}$ Ed. $2^{\text {nd }}$ Revised printing. New York.12, 543-547

[2] Hankin, L., \& Hanna, J.G., 1984, Quality of ice cream and ice milk. Bull Contecticuit Agric Exper Stat., 818, 6

[3] Joshi, D.R., Shah, P.K., Manandhar, S., Sharma, S., and Banmali, P., 2004, Microbial quality of ice cream sold in Kathmandu. Journal of Nepal Health Research Council, Vol. 2 No. 2 pp. $37-40$

[4] Fuhr, R., 1986, Bacteriological quality of different types of ice cream and milk shake during 1980-1985. In Arbeitsstagung des Arbeitsgebietes "Lebensmit-telhygiene" Leitthema: Forschung und praxis der Lebensmittelhygiene, Vom 9-12, pp. 257-261. Garmisch-Partenkirchem, Giessen/Lehn

[5] Harrigan, M. F., and McCance, M. E., 1976, Laboratory methods in food and dairy microbiology. Academic Press, London, England. pp. 193

[6] Rahman, M. M., 1997, Practical food microbiology, Bangla Academy, Dhaka Bangladesh, pp. 70

[7] American Public Health Association, 1953, Standard Methods for Examination of Dairy Products. $10^{\text {th }}$ ed APHA. Inc., New Yord, pp. 144 and 147-148

[8] American Public Health Association, 1960, Standard Methods for the Examination of Dairy Products. $11^{\text {th }}$ ed. APHA Inc., New York.

[9] American Public Health Association, 1958, Recommended methods for the Microbiological Examination of Food APHA Inc., New York.

[10] ISO,1995, Recommendation of the meeting of the subcom- mittee, International Organization for Standardization, on meat and meat products. ISO/TC-36/Sc- 6 . The Netherlands. $10-18$.

[11] Gomez, K. A., and Gomez, A. A., 1984, Statistical procedures for Agricultural Research. John Wiley \& sons. Inc. New York. p. 140

[12] USPHS, 1965, Standard method for examination of milk and dairy product. 11(2), 64

[13] Marion, V., 1954, Maximum limits of bacterial count in ice cream. Ann. Sanita Pubbl. 13(4), 1075-82

[14] Frazier, W. C., and Westhoff, D. C., 1958, Pasteurized milk in Milk Ordinance and Code, USPHS, Food Microbiology. $1^{\text {st }}$ ed., Mc Graw-hill Inc.; New Delhi, pp. 112.

[15] James, M., and Jay, J. M., 1978, Indices of Food Sanitary quality and microbiological standards and criteria. Modern Food Microbiology, $2^{\text {nd }}$ ed. p. 311.

[16] Siva, C. V.; Dilp, A., and Sannabhadti, S. S., 1993, Microbiological status of raw and pastarized milk. Indian Journal of Dairy Science, 46(1), 125-145.

[17] Pelezar, J.; Michael J, R.; Ger, R., and Reid, D., 1965, Food and water borne infections of man Microbiology $2^{\text {nd }}$ edi. USA. Chap 27. pp. 436-437

[18] Food and environmental hygiene department, 2001, Microbiological risk assessment of Ice-cream. Risk assessment studies report no. 7, Hong Kong.

[19] Orallo, G.O., Pangan, A.H., and Cabrera, E.C., 1999, Microbiological analysis of ice cream produced by big scale and small scale manufactures in Metro Manila. Phil J Microbiol Infect Dis. 28, 99-101.

[20] Bhusan Reddy, B.B., Kotinlinga Reddy, Y., Ranganadham, M., and Padmanabha Reddy, V., 1994, Bacteriological quality of ice cream marketed in Tirupati a pilgrimage town of India. J Food Sci. \& Tech. 31,151-152. 